\title{
Knowing, believing, living in Africa: A practical theology perspective of the past, present and future
}

\begin{tabular}{|c|c|}
\hline \multicolumn{2}{|c|}{$\begin{array}{l}\text { Author: } \\
\text { Gordon E. Dames }{ }^{1}\end{array}$} \\
\hline $\begin{array}{l}\text { Affiliation: } \\
{ }^{1} \text { Department } \\
\text { Practical and S } \\
\text { Theology, Uni } \\
\text { Africa, South A }\end{array}$ & $\begin{array}{l}\text { ff Philosophy, } \\
\text { Systematic } \\
\text { versity of South } \\
\text { Africa }\end{array}$ \\
\hline $\begin{array}{l}\text { Note: } \\
\text { This article wa } \\
\text { presented as a } \\
\text { the } 2012 \text { Joint } \\
\text { of academic sc } \\
\text { the fields of re } \\
\text { theology at th } \\
\text { Religion and T } \\
\text { University of } K \\
\text { Pietermaritzbu }\end{array}$ & $\begin{array}{l}\text { s originally } \\
\text { paper at } \\
\text { Conference } \\
\text { ocieties in } \\
\text { ligion and } \\
\text { e School of } \\
\text { heology of the } \\
\text { waZulu-Natal, } \\
\text { urg. }\end{array}$ \\
\hline $\begin{array}{l}\text { Corresponden } \\
\text { Gordon Dame }\end{array}$ & $\begin{array}{l}\text { Ice to: } \\
\text { s }\end{array}$ \\
\hline $\begin{array}{l}\text { Email: } \\
\text { damesge@uni }\end{array}$ & isa.ac.za \\
\hline $\begin{array}{l}\text { Postal address } \\
\text { PO Box 392, U } \\
\text { South Africa }\end{array}$ & nisa 0003, \\
\hline $\begin{array}{l}\text { Dates: } \\
\text { Received: } 04 \text { N } \\
\text { Accepted: } 02 \text { S } \\
\text { Published: } 12\end{array}$ & $\begin{array}{l}\text { May } 2012 \\
\text { Sept. } 2012 \\
\text { Feb. } 2013\end{array}$ \\
\hline $\begin{array}{l}\text { How to cite th } \\
\text { Dames, G.E, } 2 \\
\text { believing, livin } \\
\text { A practical the } \\
\text { perspective of } \\
\text { present and fu } \\
\text { HTS Teologiese } \\
\text { Theological St } \\
\text { Art. \#1260, } 9 \text { p } \\
\text { dx.doi.org/10. } \\
\text { v69i1.1260 }\end{array}$ & $\begin{array}{l}\text { is article: } \\
\text { 013, 'Knowing, } \\
\text { g in Africa: } \\
\text { ology } \\
\text { the past, } \\
\text { ture', } \\
\text { e Studies/ } \\
\text { udies 69(1), } \\
\text { Jages. http:// } \\
\text { 4102/hts. }\end{array}$ \\
\hline $\begin{array}{l}\text { Copyright: } \\
\text { (C) 2013. The A } \\
\text { Licensee: AOS } \\
\text { OpenJournals. } \\
\text { is licensed und } \\
\text { Creative Comn } \\
\text { Attribution Lic }\end{array}$ & $\begin{array}{l}\text { uthors. } \\
\text { IS } \\
\text { This work } \\
\text { ler the } \\
\text { nons } \\
\text { ense. }\end{array}$ \\
\hline 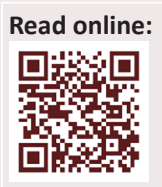 & $\begin{array}{l}\text { Scan this QR } \\
\text { code with your } \\
\text { smart phone or } \\
\text { mobile device } \\
\text { to read online. }\end{array}$ \\
\hline
\end{tabular}

The new democratic era in South Africa brought Western cultural influences forcefully into public and private living domains. This dichotomy deformed African cultures in many ways (Bujo \& Muya). Local communities were previously 'public people' living and worshipping in transformative hermeneutical communities. This scenario has changed and local communities are steadily being driven into private spaces. The task of practical theology is to question what the undergirding epistemology and beliefs for this shift are and to reinterpret it in the light of the gospel. The impact of Western culture on African traditional villages is telling in so far as traditional African values and practices are being lost at the expense of Western ideology, technology, media, et cetera (Bujo \& Muya). We argue that the former dominant monodisciplinary approach of practical theology contributed to a growing private individualist worldview. Practical theology has since developed into an interdisciplinary approach. This newfound reciprocity in the social sciences led to constructive change in church and society (Dingemans). Practical theology in Africa has to deal with an individualised, pluralistic world and tendencies of discontinuity, uncertainty, violence and destruction. In South Africa, practical theology is called upon to redress the dichotomies and defaults of Western and African cultures, respectively.

\section{Introduction}

The South African society faces a renewed challenge to reconnect its diverse cultures so that it can enable and secure social cohesion. This is an emerging crisis where people are not able to communicate and live meaningfully in a multicultural world (Koopman \& Vosloo 2002:37-40). The pluralistic realities in life require an effective methodology that can respond to such a challenge. Transversal rationality within a linguistic intersubjectivity praxis is proposed as methodology to deal with the complexity of diversity (Osmer 2008:172; Lanser-Van der Velde 2000:74-75). Disciplines in the social sciences are viewed as 'networks that transverse one another and share the common resources of rationality' (Osmer 2008:172). Transversality is specific to a person and a perspective or a community and a culture. It explores various factors which overlap and diverge in concrete dialogue between the cultural perspectives of particular communities (Osmer 2008:172). Transactional cultural change through intersubjectivity, specifically linguistic intersubjectivity, is sought (Lanser-Van der Velde 2000:28-29). People and their contexts influence and change one another. Cultural identity is being influenced reciprocally by one specific community and another's context (Lanser-Van der Velde 2000:48). Transforming cultural praxes resonate with one of the aims of practical theology, namely to change praxis.

This article seeks to focus on two questions: (1) how the gospel and culture, particularly in multicultural contexts, interact within the framework of practical theology and (2) how practical theology could help the church to create a new culture to serve as a bridge between multicultural praxes. By considering these questions, we shall, firstly, introduce the problem; secondly, present culture as a reciprocal agency; thirdly, propose a new culture of knowing, believing and living; fourthly, present a contemporary contextual framework and, fifthly, propose the transformation of practical theology and conclude the article.

\section{Culture as a reciprocal transformational agency}

Christianity is confronted with challenges worldwide as it faces new cultures in its attempt to develop its identity (Hastings 2007:viii). Robinson (2006) avers:

[W] e are truly living between [modern and postmodern] paradigms and that is not a comfortable place to be. The experience of living between paradigms is not a new one for the church. (p. 12)

Mwambazambi (2011) adds his voice to this argument in the following way:

The impact of globalisation on the religious lives of the people of Africa challenges African churches to contextualise the Gospel with a trans-formational hermeneutic in engendering an affirmative new African 
faith civilisation. Globalisation is having an equally decisive impact upon the religious universe of African civilizations; ... how the Gospel can, through the African churches, prepare a new civilisation which, as Bediako (1990:85) said, 'will allow us to live in the age of Africa's faith and confidence in God.' (p. 1)

Over and above these challenges are a number of constants, for example biblical, historical, contextual, scientific and cultural developments that determine the perspective(s) of practical theology. These constants provide a framework for new developments in the field (Viau 1999:x). Fowler, for example, according to Osmer and Schweitzer (2003:1) holds that the critique of culture is responsible for a redefinition of practical theology. As public theology, it offers a critical analysis of and redress to limitations in contemporary culture, religion and practical theological perspectives (Osmer \& Schweitzer 2003:7). If Anderson's (2001:14) view that 'the core theology of the Bible ... is practical theology' is accepted, it should follow that practical theology needs to contextualise the gospel consistently in terms of its immediate culture (Robinson 2006:13). In Newbigin's (1986:3) definition, culture is '... the sum total of ways of living developed by a group of human beings and handed on from generation to generation.' The church continuously enters phases to engage creatively in its mission to change the world. Therefore its relationship with the existing culture needs to be renewed (Robinson 2006:46). Today the church is in an emerging new culture and is confronted with deep-level challenges. These tectonic cultural shifts fragment the relationship and reconnection of systems, relationships and communities (Taylor 2005:19). A new radical rethinking of every cultural facet about the church is called for (Robinson 2006:47). Suffice to say that the church needs to find expressions of the Christian faith within both traditional and new cultural contexts. Theology is shaped by contextual factors such as people's socio-political, economic and cultural experiences. Winter (in Robinson 2006:72) notes the importance of cultural exegesis to reflect on the subcultures that form around Christian communities. Cultural identity is a prime locus or theological source for the construction of contextual theologies. This is a valid way of doing theology in a particular context (Bevans 2005:25). However, an attempt to apply cultural identity as a theological source can default into cultural romanticism - fantasies about the existence of an African 'fossil culture' before colonisation, should be avoided (John Pobee in Bevans 2005:25).

Keifert's (2006:39) theory of cultural and mission transformation undergirds his theory of congregational development and missional enhancement based on spiritual discernment or practical wisdom or reason. He argues for the transformation of culture to realise systematic and organisational change. However, Bosch (1995:24-25) called on a culture which would regain an appropriate comprehension of humanity itself. In terms of their existential realities, local faith communities are critical in the formation of life and in how they facilitate discourse that engenders engagement with surrounding cultures (Bosch 1995:60). Van der Ven (1994:x) refers to a structural aspect of culture as a reciprocal transformational agency in being influenced by its surrounding culture and as a self-regulating social context that can change itself. Practical theology should therefore rethink its role concerning the meaning of culture within the academy, society and church.

\section{The gospel and non-Western culture from a South African perspective: A framework of the past, present and future}

South Africa's history concerning the role of 'the gospel and Western culture' led to enculturation, dominance and the rejection of a Western cultural gospel (Adonis 1982; Bosch 1995; Tshaka 2007). The argument that many missionaries with a Western cultural agenda have distorted, replaced and even destroyed indigenous African cultures (Bujo \& Muya 2003) has been disputed by Newbigin (1997:2). He argues instead for an appreciative valuation of the contributions of the world missionary movement. However, the impact of Bujo and Muya's (2003) views still resonate and will continue to affect traditional African cultures to some degree (Tshaka 2007). Bevans (2005:25) accentuates this fact by arguing that 'much of the richness of many local cultures has been ignored and suppressed'. Apartheid rule deformed Christian identity and practices under the illusion of Christian principles. This legacy continues to complicate interracial relationships and the development of constructive social capital (Dames 2012:12; Cilliers \& Nell 2011:4-5). The fact that the Christian church today is statistically predominantly an African society could serve as a corrective - it simultaneously has an obligatory agency for a new visionary perspective on South Africa's multicultural reality (Newbigin 1997:1; Dreyer 2008:7-8; Tshaka 2007). This obligatory and visionary agency calls on all South Africans to become 'culture creators' in the recreation of a new cultural identity (cf. Branson 2011:400ff).

The ecumenical church in South Africa, as a model of 'new culture creators', challenged and transformed the previous political order (Cochrane, De Gruchy \& Petersen 1991). The former Dutch Reformed Mission Church (DRMC), for its part, announced a status confessionis (1982) in declaring that the justification of apartheid and the theological justification thereof were unbiblical and immoral (Botha \& Naude 1998). The DRMC's declaration of the Confession of Belhar (1986) constituted a public confession that helped to espouse the transformation of church and society with the values of unity, reconciliation and justice. The question of how this public encounter could assist in the transformation of new and complex challenges is again relevant in South Africa: '[T]here is a hopeful element within South Africa's religious approaches to public affairs' (Kuperus 2011:305). This holds especially for the complex relationship between gospel and culture within interdenominational, traditional, independent and charismatic churches in South Africa. Kuperus (2011:305) refers to Gifford's thesis regarding the South African case study as a macro-oriented public engagement towards the 
reconstruction, reconception and transformation of Christian life and public conditions.

\section{The dynamic between gospel and culture}

How do we reflect on diverse cultures and the gospel or our Christian faith and simultaneously change static praxes through reflexive and transformative action? The work of Newbigin (1986, 1989) is critical in this regard. Newbigin $(1986,1989)$ demonstrated, through his own life, how the church's mission could change cultures. He illuminated how Western culture continues to impact negatively on Africa: The new era of the Enlightenment during the 18th century birthed 'the conviction that Europeans now knew the secret of knowledge and therefore the secret of mastery over the world' (Newbigin 1986:23). This Eurocentric conviction led to numerous hegemonic practices such as white supremacy and world dominance. Another default position is the dichotomy between the private and the public world, which led to the construction of questionable ideologies and a 'pie in the sky' gospel message (Newbigin 1989:132). The dualism between private and public continues to affect local and international cultures. Individualism in contemporary Black religious life, for example, regenerated and reinforced the domination of personal salvation and religious piety in American Christianity (Andrews 2002:92). The public world refers to the world of universally acceptable facts. The private world is the world of values with the freedom of choice and the pursuit of personal gain. This tendency may resonate with the fact that Western missionaries in the past focused their hearers' attention on a future hope (in heaven) whilst ignoring contemporary existential suffering. The same is true of the conduct of public officials who defraud public funds for personal gain at the expense of the plight of poor people (Dames 2009:121; Sampson 2009:131). 'Private theology' fostered trends in white South African churches to live and worship in safe cultural enclaves whilst simultaneously discriminating against people of another culture (Cilliers \& Nel 2011:4-6; De Beer \& Van Niekerk 2009:51-53). The Dutch Reformed Church in South Africa is both the 'preserver and defender of the flock' according to Kuperus (2011:286, 288). The same scenario is also apparent in American individualism which prevailed upon both religious and secular Black life (Andrews 2002:92).

\section{A static religious praxis}

The impact of Western culture on African traditional cultures is telling in so far as African cultural values and practices are being lost at the expense of Western technology, media et cetera (Bujo \& Muya 2003; Bediako 1999). Even AfricanAmerican people are facing resilient and unrelenting oppression. Andrews (2002:1465) notes that churches can become static in their responses to the 'overwhelming exigencies of mere coping'. A large part of the failure to change things can be ascribed to a lack of understanding of how or even what to change. The displacement of Black churches from their traditional centrality in the Black community heightens the critical need of scholarship in practical theology for both African-American folk religion as well as South Africa's multiracial people (Andrews 2002:1465; Dames 2012). The new democratic era in South Africa forcefully brought to the fore Western cultural distortions in both its public and private worlds. This scenario drove many people into private safe places. The task of practical theology is to question the rationale behind this in the light of the gospel: 'There is no genuinely missionary encounter of the gospel with our culture unless this happens' (Newbigin 1989:132; Bosch 1995). According to Branson (2011:367) '[a] Church's missional life is at the core of God's gospel engagement with the world'. Many churches in South Africa are presently stuck because their members opted for private safe enclaves instead of public engagement with existential issues (Dames 2010; Cilliers \& Nel 2011:4; De Beer \& Van Niekerk 2009). Concerning the gospel, Newbigin (1989:144) asked: 'How far should the gospel be "at home" in a culture, and how far should it resist domestication? What is true contextualization?' We concur that the church's public missional vocation can liberate it from any form of domestication. Newbigin (1989) argues that:

[t]rue contextuality happens when there is a community which lives faithfully by the gospel and in that same costly identification with people in their real situations as we see in the earthly ministry of Jesus. (p. 154)

There is a constant need for a new creative role for theology in a new South African public space (Laubscher 2007:1555). Faith communities are basically hermeneutics of the gospel, guarding against the domestication of the gospel. The gospel ought to call every human culture into question, based on Christ's redemptive work 'that alters the total human situation' (Newbigin 1986:3-4). The gospel ought to confront Western and African cultures with the authentic crucified Christ as Christopraxis (Newbigin 1986:9; Anderson 2001:14, 29). A missionary encounter of the gospel with the (post) modern world must demand a radical conversion that transcends plausibility structures (Guder 2000:96; Robinson 2006:73-74). The most real of all realities is the living God - the reality as a whole (Newbigin 1986:90). The place of Christianity should always be on the outside of the establishment and on the side of its victims (Newbigin 1986:125). Congregations should shape their relationships and activities to care for strangers, migrants and those who are excluded by a dominant culture (Branson 2011:373-374). The Confession of Belhar proclaims precisely this, to stand where God stands, on the side of the sufferer, people on the edges of society. It is from here that the Christian Church can be a public witness that can encounter Western culture's default domestication of the gospel. Practical theology should reflect on this bipolar tension between gospel and culture and seek to build hermeneutical faith communities for the church's public missional vocation within African cultures. The World Council of Churches' study 'Gospel and culture' argues for 'the need to hold together the different cultural expressions of the Christian faith' (Newbigin 1997:5). Practical theology, in particular, 'calls the church back to its roots as a fundamentally missionary church with a particular vision and specific task to perform in the world' (Torrance in Anderson 2001:33). 


\section{Towards a new culture of knowing, believing and living}

A strong and realistic cultural identity is critical if theology relates authentically 'to a context in its particularity' (Bevans 2005:26). The Christian faith as a prophetic religion should reconstruct the fragmentation, destruction and brokenness in our individual lives and diverse cultures (Volf 2011:190). Practical theology, through its reflexive quality of praxis, is tasked to bridge the gap 'between living in the world and living in a faith community' (Andrews 2002:29, 35). In the worlds of Newbigin 1986):

Christian religion [is] fundamental to any culture, a set of beliefs, experiences, and practices that seek to grasp and express the ultimate nature of things, that which gives shape and meaning to life, that which claims final loyalty. (p. 3)

The key question in South Africa should be: How do we deal with knowing, believing and living amongst diverse cultures in the light of the gospel? The answer may lie in what Branson (2011:400-405) proposes from a praxis approach in practical theology and based on Freire's praxis model of meaningful social change for people. Freire's notion of people as 'culture creators', as referred to above, is significant for how we deal with diverse worldviews and multicultural challenges in South Africa. It can bridge the gap between South Africa's diverse cultures or multiracial people. Local faith communities offer agency to shape meaningful cultures and social contexts through their own praxis in relationship with the world, ' $[b]$ ecoming participants in creating the culture they live in' (Branson 2011:405). Branson (2011:412) believes that Freire's concept of praxis can help church leaders to extend reflexive practices in their ministry context by also engendering the transformation of their congregations and their social contexts. Andrews (2002:79), from a Black Theology perspective, emphasises this view and argues from an ethnic geographical perspective: 'Every church also has a praxis concerning how they as a whole view and interact with their geographic neighbours or with persons from different ethnic backgrounds.' Volf's (2011:190) reconstructive Christian faith theory above correlates with Andrews' 'reconception' of the faith theory which is both undergirded by Branson's notion of ministry and social reflexivity and by change. Andrews argues from a position that is specific and that can be characterised as localised, African-American, 'religious folk life', which was shaped through particular cultural historical and contextual experiences. These theories of reconstructive Christian faith, reconceptual (African) faith life and change are instrumental in the creation of a new kind of (Christian) culture within (post)modernity (McLaren 2001). This possibility is undergirded by Volf's (2011:1954) theory that there are 'many non-Western ways to modernise'. It is a paradigm shift from traditional theories which hold that modernisation resides only in Western worldviews and cultures. Taylor (in Volf 2011:1954) refers to 'multiple modernities' in the light of worldwide economic progress, technological advances, knowledge development and transference ' $[T]$ he fastest growing worldviews are religions - Islam and Christianity - and not secular humanism'
(Volf 2011:1954, 1968). This fact should be embraced as a creative agency to shape new cultures in the light of God's mission for the world. The contemporary world is a religiously diverse place. This is an example of a new plausibility structure for interaction between the gospel and diverse cultures (Robinson 2006:73-74). Christianity is now also predominantly a non-Western religion and 'more public in a politics of multiple communities' (Volf 2011:1968, 1996). We contend that the Gospel and Culture Network must have inspired most of these religious gains in the world as well as the reflexive praxis between the gospel, Western and now nonWestern cultures (Bosch 1995). This offers us an opportunity to recreate and transform the complex multicultural or racial challenges in local churches and society. Such an experiment should be placed within a contemporary contextual framework. The following paragraph presents the views of pastors on the relationship between gospel and culture, and the role of practical theology therein.

\section{A contemporary contextual framework}

A small-scale, qualitative empirical study was done at the Northern Theological Seminary on 18 November 2011. A random sample of pastors of the Uniting Reformed Church in Southern Africa (URCSA), who have been in the ministry for one to five years, was used. The pastors are themselves representative of multicultural backgrounds and represent multicultural congregations in the Gauteng and Mpumalanga provinces. A semi-structured questionnaire was used to determine the pastors' observations of the existential experiences of church members and their own perceptions about the role of practical theology therein. Four respondents out of a total of 10 responded. The results of this experiment cannot be generalised. The following findings were recorded.

Respondents confirmed that issues such as discontinuity, uncertainty, violence, destruction and individualism have a direct impact on life and work in the faith communities they serve. Most $(n=3)$ respondents confirmed that the lives of people in local communities could be described as public. They concurred that certain Western cultural influences have a direct negative effect on the experiences, perceptions and behaviour of people in local and traditional African communities. The respondents described these influences as destructive of family units and creating a vacuum in society, and they cite family violence, prostitution, preoccupation with technology at the expense of family and community values, the devaluing of African culture and the notion of being primitive, the replacement of African cultural music and attire and the dominant role of Western music in African worship services. The observation of one respondent about being 'a stranger in one's own African culture' describes the extent to which Western culture influences African culture. The dichotomy between poor people who live public lives and wealthy people living private lives exacerbates the divide in traditionally $u b u n t u$ communities.

On the question of the role of practical theology in the light of the aforementioned challenges, respondents argued 
for a practical, contextual and functional approach. The responses varied from the need for practical wisdom without being 'academically loaded for the people in the pews' to addressing issues such as personal morale development, economic challenges, counselling for the victims of witchcraft and homiletics on Satanism, witchcraft and even stewardship. One respondent called for the visible embodiment of 'our African spirituality in our worship services' to engender new community responsibility towards justice, love and unity in church and society. We concur that the dominance of Western culture over African cultures and the domestication of the gospel in African contexts lie at the root of the abovementioned existential conditions of church members. What should be the response of academic practical theology in the light of these challenges?

\section{The transformation of practical theology}

The existential realities of the past, present and future necessitate an interdisciplinary or rather a transversal rationality approach in practical theology (Osmer 2008:327ff; Van den Berg 2010). The complexity of South Africa's historical, contemporary and future context and a reflexive theological praxis calls for an approach to tackle both the convergence and divergence in diverse perspectives of cultural, public and Christian life (Bosch 1995; Osmer 2008; Newbigin 1989). Postmodernity, in addition, requires practical theology to deal with an individualised, pluralistic world and growing glocal tendencies of criticalness, uncertainty and human destructiveness (Janse van Rensburg 2002, 2007; Patton 1988:31). Practical theology has developed from a monodisciplinary to an interdisciplinary approach in reciprocity with the social sciences - searching for constructive change in church and society (Dingemans 1996:83, 91). This shift facilitates a constructive contextual approach in critical reflection, theory development and new praxis development with reference to our empirical findings above within specific and localised episodes, situations and contexts (Osmer 2008:11-12). Hendriks' (2001:16) approach for doing theology in an African context is illuminating.

Practical theology within specific contexts holds the bipolar tension between its function as a discerning discipline and its cultural formational identity in time and space to engender hermeneutical public missional spaces within church and societal contexts. The empirical findings have emphasised the problem of African cultures which are being smothered by Western influences and the need for constructive, relevant and contextual practical theology. Suffice it to argue that we need to reflect on how practical theology should face the dilemma of African cultures versus Western culture, the domestication of the gospel and how it should function in developing a public missional hermeneutical community. The church should resist indifference to existential realities in the public domain but should nurture the intimate bond between public and theology within a critical dialogical distance, according to Barth (in Laubscher 2007:1556-1557).

\section{Developments in practical theology in the 21st century church and society}

Schleiermacher's (in Heitink 1993:16) renowned definition of practical theology as a scientific discipline may have caused the contemporary church more harm than good. Rifts develop even today between the academy of Black theology and Black churches (Andrews 2002:35). Practical theology may have inadvertently functioned in a private scientific space without engaging adequately with the existential public conditions of church and society. Contemporary voices call on practical theology to become more contextual, practical or relevant rather than being a highly theoretical discipline with a growing distance between the academy and the local church (Naidoo 2010:347; Tucker 2011; Viau 1999:xi). We should guard against a renewed emphasis on the dominant role of ecclesial and clerical models of the past instead of on hermeneutical faith communities in specific contemporary contexts (Hastings 2007:2). Such a focus may lead to various systemic and hegemonic leadership practices in church and society (De Beer \& Van Niekerk 2009). In the 20th century, the emphasis in practical theology has shifted away from ecclesial and clerical models due to the constructive impact of the social sciences on practical theology (Heitink 1993). This shift has facilitated the deconstruction of privateoriented theological enterprises and motivated more public theological engagements (Laubscher 2007:1551). Suffice it to state that a paradigm and/or methodological shift in practical theology followed (Van der Ven 1994). However, the findings of our empirical study indicate little evidence of the reality of this shift. Since the 1980s, the focus has changed to hermeneutical and empirical approaches (Bam 1984; Burger 1991; Heitink 1993).

The complexity of life requires better understanding, interpretation and application of new knowledge. Freire (in Branson 2011:401) wants knowledge to serve a lifegiving role in nurturing persons and communities to change their contexts whilst they themselves are being changed through the reflection-action cycle. Practical theology is challenged to search for sound theological theoretical and empirical direction and a renewed engagement between praxis and theory (Dreyer 2002). An oversimplified quo vadis question, where to with practical theology, for a 'redramatisation' within theological disciplines and through a theodramatical approach, may not be the solution if it remains a 'pure' academic experiment (Nel 2009). The social sciences brought about a renewed perspective on practice itself and engendered a new focus on the study of church practices (Dingemans 1996:83). Consensus on methodology has been achieved (Dreyer 2002; Hendriks 2001; Osmer 2005; Pieterse 2001; Van der Ven 1994). However, a refocusing on practical theological principles is underway. Theoretical studies on normativity have become an important subject in recent studies (Dingemans 1996:93; Osmer 2008). The need for a redress of the current moral vacuum and cultural fragmentation in society is critical (Dames 2009:5-7; Koopman \& Vosloo 2002:78). For instance, Firet, quoted by Burger (1991:14), never viewed practical theology as norm- 
less or as ordinary, pragmatic and functional, but he did view it as authentic theology. Firet's scientific approach to communicative action, based on empirical phenomenological findings, makes him one of the most important practical theologians (Burger 1991:14). The focus shifted away from the deductive (objective) approach because of his hermeneutical and contextual perspective based on the normative role of scripture (Burger 1991:13). Newbigin's contribution of the relationship between gospel and culture in order to deal with existential conditions is critical. Practical theology as crisis science needs to redress the dwindling authority of scripture, church, leadership and local cultures, as well as the discontinuity between church and society (Heitink 1993:15; Keifert 2006; Roxburgh 2005; McLaren 2001). This crisis is synonymous with abstract and cognitive theological education, which leads pastors' practical actions towards a technological or functional theology (Heitink 1993:15; Naidoo 2010:351). Scholars proposed the transactional methodology by means of which practical reason and actions interact within an intersubjective reflexive engagement between gospel and faith on the one side and culture on the other side (Lanser 2001:74). It is a reciprocal transactional approach that reflects on and facilitates the interaction of gospel and culture, values and knowledge and public and private through transversal rationality. Multicultural elements lead to divergence regarding differences and convergence regarding constants. Diverse communities can transact reciprocally to create a new culture or worldview. Through language, new meaning is created by transactional and intersubjective approaches (Dewey 1938:44). Communication is formative and leads to new experience (Dewey 1916:6, 11). Communication is a transformational action that transforms old habits, perspectives, experiences and situations meaningfully towards new possibilities. The respective subjects relate intersubjectively to one another. Ongoing interaction between humans and situations and among human beings leads to ongoing and multiple changes and the creation of new meaning (Dewey 1951:41ff; Habermas 2001:x).

Intradisciplinarity is thus crucial if the practical theological gains from the social (linguistic) sciences are to be integrated to engender hermeneutical and reflexive faith or multicultural communities with a public missional vocation (Van der Ven 1994:7-9; Lanser 2001:74). According to Heitink (1993), practical theology is thus:

... an action science with an empirical-orientated theological theory for the mediating of the Christian faith in the praxis of the modern cultural society - towards the actual transformation of these praxes. (p. 18)

Numerous new trends in the field of practical theology were the result of its ability to merge with and reflect (from a critical distance) on the social sciences. The answer to the question of undergirding epistemologies and beliefs in Western culture and dealing with discontinuity, uncertainty, violence and destruction lies in the manner how future studies in our field could help close and resolve today's chasms and existential problems (cf. Van den Berg 2010).

\section{Practical theology - a future response towards transactional constants}

The current holistic practical theological focus in South Africa on concrete and practical contemporary challenges demonstrates the need for appropriate and relevant theology (Dames 2010; Dreyer 2009:17; Janse van Rensburg 2009:28; Landman 2009:35; Meylahn 2009:42; Müller 2009:46; Pieterse 2001; Wepener 2005). These perspectives will set the agenda for future studies in South Africa. The importance of historical studies, Bosch's (1995) and Newbigin's (1986, 1989) perspectives above, is also paramount. Practical theological historical studies, aligned with a critical-reciprocal hermeneutical approach, represent a new perspective. They study church tradition, human experience, culture, normativity and factuality - from a Christian-faith tradition and scripture perspective (Heitink 2000:549). Thus, dissolving the tension between normativity and experience informs the relationship between gospel and culture (Dreyer 2002). Such an approach could prove crucially important for the South African public's journey towards racial reconciliation and social justice (Dames 2012:9).

The rebirth of practical theology has been called for by focusing on practical reason in an attempt to face existential problems in social reconstruction, especially with reference to the transformation of static cultures. Practical reason is a dynamic interpretive and re-interpretive hermeneutical process (Browning 1991:2-4, 10-11, 15). Practical theology should thus function at the centre of the social or cultural context, where the theologian and the church mediate the gospel (Anderson 2001:26). Suffice to caution for a tendency of culture to determine what is normative in reality apart from God's self-revelation (Anderson 2001:21). However, there remains considerable discrepancy between theological reflection and pastoral action within most contemporary cultures (Viau 1999:x). The need for counselling of victims of witchcraft and homiletics on Satanism according to the empirical responses serve as an example. The communication of the gospel is also at risk in terms of the life experience or complex cultural dynamics of human souls (Louw 2004:1). To deal with the discrepancy and risk Viau (according to Heitink 2000:538-539) introduces a theoretical basic theory as a link between discourse in the faith praxis, contemporary cultural experience and language. A comprehensive hermeneutical approach is essential for an understanding and interpretation of human existence within 21st century contexts (Louw 2004:1). Lindbeck's (in Newbigin 1996:34-36, 38) cultural-linguistic theory is illuminating in this regard. He applies the Bible as a narrative that structures human experience and understanding. The appropriate use of language can transform fragmented cultural realities between humans, society and the church (Dingemans 1996:86-87, 89). It enriches action and reflection, especially, where traditional uniformed perspectives and methodologies are being replaced by a plurality of philosophies and actions (Viau 1999:xi). Pluralistic and diverse cultural relationships are not to be defined only by religious and cultural differences, but by 'overlaps' and 'common principles' too, based on moral 
principle of equality, fairness and justice (Volf 2011:2254). Practical theology should, therefore, guide pastors in communicating the gospel in an understandable language, particularly within diverse and complex cultural contexts (Viau 1999):

Language [is] the complete gesticulatory and verbal universe of the human being - it has symbolic meaning at the heart of a given culture. (p. xii)

Language is fundamentally a hermeneutical practice (Viau 1999:xii; Pieterse 2001:72-77). The notion of 'language culture creators' is instrumental for a theology of fides quarens verbum, a faith which seeks public discourse to reshape traditional language in relation to diverse cultures (Viau 1999:xiv). This is a shift from Anselm of Canterbury's (in Viau 1999:xiii) definition of theology as fides quarens intellectum, faith seeking understanding that does not focus on the role of theology in the communication of faith. Suffice it to concur with Viau (1999:xvi) that the capacity of practical theology to capture the faith practices of Christians lies in the effectiveness of its linguistic apparatus. The role of practical theology is therefore to reconstruct any linguistic apparatus that does not consider fragmented or diverse cultural living practices (Dames 2012:10). Newbigin (1986) claims the following:

Central to culture is language. The language of a people provides the means by which they express their way of perceiving things and of coping with them. Around that center one would have to group their visual and musical arts, their technologies, their law, and their social and political organisation. (p. 3)

Theology is thus practical because it is based on human experience in an interactive linguistic community through linguistic intersubjectivity (Viau 1999:195; Hastings 2007:10; Lanser-Van der Velde 2000:74). Note should be taken that, according to Heimbrock in Immink (2005:4), an empirical approach to the praxis of faith does not do justice to the phenomenon of 'believing'. He therefore pleads for a phenomenological approach to highlight the unique character of humans' faith reality. Grözinger (in Immink 2005:4) argues for an aesthetic approach to illuminate, for example, the concept of God's revelation and people's experience of God through artwork. Aesthetical practical theology and Christian language practices are thus essential in the creation of meaning in a fragmented and secularised culture (Viau 1999:xii, 195, 206) - by integrating its meaning in faith practices and human experiences (Cilliers 2002:44, 2009; De Klerk, De Wet \& Letšosa 2011). African art and music could be instrumental in bridging the gaps between the gospel and diverse cultures. This is a subversive transformational process of African people to counter the external influence of popular culture. Western-imposed frames of references are thus reconfigured and reemployed for their own culture (Taylor 2005:36-37). Cilliers' (2002) views on preaching as play, a homiletically aesthetical perspective on postmodernity, and Louw's (2009) use of aesthetics in pastoral theology are not only illuminating but also essential to fostering a new Christian imagination and vision for a new African cultural reality. The need is for homiletics on Satanism and stewardship, especially the visible embodiment of an African spirituality in worship services.
For this reason, the habitus model could also establish its importance in spiritual formation and growth in wisdom within a pluralistic and diverse cultural society (Ballard \& Prithard 1996:1-3, 68). The training of religious leaders with new spirituality habits and skills is crucial to tackling plurality and diversity in congregations (Walther 2009; Naidoo 2010).

Missional theology, according to Bosch (1995) and Newbigin (1986, 1989), may be instrumental in fostering a holistic practical theology approach to attend to socioeconomic, cultural and environmental and political challenges - by realising the Christian witness concretely through Christian vocation (Ballard \& Pritchard 1996:3, 23). A new missional approach which merges practical and missional theology informs current practices in Africa, Asia, North America, Europe and South America (Hastings 2007:viii,ix). Hendriks (1994, 2001), Marais (2006) and Nel (2002) represent the South African perspective on missional practical theological. According to Anderson (2001:31): 'Mission theology is an integral part of practical theology.' This perspective can help to engage complex cultural dynamics between ecclesial or trans-ecclesial Christian practices, theoretical studies and marginalised realities (Hastings 2007:2-3, 37). Practical theology will progress if it informs a 'missional-cultural ecumenical' approach between and in multicultural contexts and assists in social transformation and development in South Africa.

Cochrane, De Gruchy and Petersen's (1991:1-2) study on practical theology during the apartheid era in South Africa remains crucial today for a new moral and social transformative pastoral praxis. They called for a reorientation of practical theology (Cochrane et al. 1991):

Even when South Africa change[s] with the possibility of a genuine post-apartheid reconstruction of society ... insights in crisis ... will remain valid ... even if we are to avoid slipping back into reactionary ways of behaving and acting under the temptations to retreat and relaxation which will come with the return and re-emergence of so much new, secular leadership and with the new forces for reconstruction. (p. $x$ )

The moral and interracial crisis in contemporary South Africa is symptomatic of our temptation to retreat and relax as 'secular leaders' rather than to live as prophetic faith-based visionaries (Volf 2011):

Virtuous character matters more than moral knowledge and faith produces devastating results when it devolves into a mere personal or cultural resource for people whose lives are guided by anything but that faith. (pp. 339, 477)

Authentic spiritual leadership is required today to apply a relevant understanding of faith to various spheres of life that would guard against using faith in oppressive ways (Volf 2011:477). Historical and current cultural occurrences of fragmentation, destruction, suffering and pain should be dealt with by an approach of recreation, restoration and healing (Dames 2010). Cura vitae, for example, is about a theology of life and the healing of life. It inculcates meaning to life within the reality of suffering, human vulnerability and the ever-present predicament of trauma, illness and 
sickness (Louw 2008:11). These pathologies in life, in the light of the empirical findings, require reflection and application in its specific and concrete moment of praxis (Müller 2005). The church is an effective agent for social transformation through a humanitarian focus on development (August 2000). It offers hermeneutical hospitality - an exchange of gifts in the practice of 'uncorrupted love' in search of truth and mutual understanding (Volf 2011:2215). The development of a new cultural vision for church and society - a restored and new moral and spiritual humanity - is essential. Osmer's (2005) new perspectives on faith formation, exhortation and discernment within local congregations can help practical theology to foster such a vision. Public practical theology and ethical theology become crucial in the creation of a new kind of Christian spiritual and moral culture (McLaren 2001; Van der Ven 1994). Fowler (according to Osmer \& Schweitzer 2003:7) developed a public practical theology within a public Christian ethical theology. Such a holistic approach is appropriate for the recreation of $u b u n t u$-like multicultural hospitality.

Pneumatology and the doctrine of human vocation could help form new patterns and systems of human cultural interaction (Osmer \& Schweitzer 2003:239). Vocation defined as diaconology is a science of studying actions which actualise and sustain the interactive relationship between God and humans and humans and the Trinitarian God (Bam 1984:8). A renewed practical theological foundation becomes crucial for Christian ministry with a focus on leadership, vocation and cultural transformation (Anderson 2001:14). Vocation guides communities around obscure cultural values which are beyond obvious empiricism (Jenkins in Moss 2009:4). Vocation refers also to our responsibilities in public life (Osmer \& Schweitzer 2003:6-7). Therefore, real-life and concrete ministerial issues should be tackled from the praxis of God (Anderson 2001:26, 29). The praxis of faith (life of faith) and the praxis of a new culture in its practical and concreteness will thus require constant evaluation and systematic reflection (Immink 2005:vii, 10).

\section{Conclusion}

Practical theology is in a place of extraordinary opportunities and challenges. These opportunities and challenges require a holistic approach based on both the hermeneutics of the gospel and contemporary culture. Practical theology should retain its theological missional normativity in its dialogue with the social sciences. The intentions and values of the praxis of God should mediate meaningful life within a pluralistic and fragmented world. The challenge is to develop 'culture creators' and practices to bridge the chasms between gospel and culture, public and private, science and experience, Western and African cultures and the divides between South African multicultural contexts. The training of a new generation of skilled spiritual and moral leaders is essential for an authentic witness and mission. Firet, Heitink and Louw's hermeneutical methodologies, combined with Bosch's, Newbigin's and Hastings' missional theology and Van der Ven's empirical research insights, are significant contributions to a world saturated with complex diverse cultural, socioeconomic and political challenges. The science of vocation, diaconology, could help to bridge narrow cognitive and technological approaches. Practical theology is a criticalhermeneutical, participatory-action and reflection study within the praxis of God for the missional praxis of the church within the praxis of society. Vocational and practical theological action ultimately defines the identity and answers the quo vadis question of the 'beroeps-pastor' [professional pastor] (Firet 1968:354), as well as how diverse multi-cultures and the gospel interact within the framework of a public practical theology, and how practical theology could help the academy, church and society to support the creation of a new cultural praxis for the convergence or overlapping of multicultural worldviews of knowing, believing and living.

\section{Acknowledgements}

Acknowledgement and gratitude for the participation in the qualitative research by the alumni ministers of the Northern Theological Seminary of the Uniting Reformed Church in Southern Africa in the Southern Transvaal and Northern Synod.

\section{Competing interests}

The author declares that he has no financial or personal relationship(s) which may have inappropriately influenced him in writing this article.

\section{References}

Adonis, J.C., 1982, Die afgebreekte skeidsmuur weer opgebou: Die verstrengeling van die sendingsbeleid van die Nederduitse Gereformeerde Kerk in Suid-Afrika met die praktyk en ideologie van die apartheid in historiese perspektief, Rodopi, Amsterdam.

Anderson, R.S., 2001, The shape of practical theology: Empowering ministry with theological praxis, InterVarsity, Downers Grove, IL.

Andrews, D.P., 2002, Practical theology for black churches: Bridging black theology and African American folk religion, Kindle edn., Westminster John Knox, London, viewed 27 December 2011, from http://www.amazon.com/Practical-TheologyBlack-Churches-ebook/dp/B005LD9E2Q/ref=sr_1_6?s=digital-text\&ie=UTF8\&qid $=1330003555 \& s r=1-6$

August, K.T., 2000, 'The Challenges of Global Developmental Issues for the Church and Theology: Toward a Hermeneutics of People-Centred Participatory Development in Theological Education', Practical Theology in SouthAfrica 15(1), 1-18.

Ballard, P. \& Prithard, J., 1996, Practical theology in action: Christian thinking in the service of church and society, Liturgical, London.

Bam, G., 1984, Diakonologie - Met 'n kort verwysing na genesing as diens van die kerk, UWK, Bellville. PMCid:1628740

Bediako, K., 1992, Theology and identity: The impact of culture upon Christian thought in the second century and in modern Africa, Regnum, Oxford.

Bevans, S.B., 2005, Models of contextual theology: Faith and cultures, rev. and expanded edn., Orbis, New York, NY.

Botha, J. \& Naudé, P., 1998, Op pad met Belhar: Goeie nuus vir gister, vandag en more, Van Schaik, Goodwood.

Bosch, D.J., 1995, Christian mission and modern culture: Believing in the future, toward a missiology of western culture, Trinity, Valley Forge, PA.

Branson, M.L., 2011, 'Theology and context', in M.L. Branson \& J.F. Martínez (eds.), Churches, cultures \& leadership: A practical theology of congregations and ethnicities, pp. 313-802, Kindle edn., IVP Academic, Downers Grove, viewed 18 December 2011, from http://www.amazon.com/Churches-Cultures-LeadershipCongregations-ebook/dp/B005JWJA8C/ref=sr 1 5? s=digital-text\&ie=UTF8\&qid= Congregations-ebook

Browning, D.S., 1991, A fundamental practical theology: Descriptive and strategic proposals, Fortress, Minneapolis, MN.

Bujo, B. \& Muya, J.I., 2003, African theology: The contribution of the pioneers, Paulines, Congo.

Burger, C.W., 1991, Praktiese teologie in Suid-Afrika: 'n Ondersoek na die denke oor enkele voorvrae van die vak, RGN, Pretoria.

Cilliers, J., 2002, 'Prediking as Spel: 'n Homiletiese Estetiese Perspektief op Postmodernisme', Practical Theology in South-Africa 17(1), 1-28. 
Cilliers, J., 2009, 'The Beauty of Imagined Meaning: Profiling Practical Theological Aesthetics', Practical Theology in South-Africa 24(1), 32-47.

Cilliers, J. \& Nell, I.A., 2011, “"Within the Enclave”: Profiling South African Social and Religious Developments since 1994', Verbum et Ecclesia 32(1), Art. \#552, 7 pages, viewed 15 January 2012, from http://dx.doi. org/10.4102.ve.v32i1.552

Cochrane, J., De Gruchy, J. \& Petersen, R., 1991, In word and deed: Towards a practical theology for social transformation, Cluster, Pietermaritzburg.

Dames, G.E. (ed.), 2009, Ethical leadership for a morally transformed society, SunMedia, Stellenbosch.

Dames, G.E, 2010, 'The dilemma and irrelevancy of traditional and 21st century pastoral care and counselling: Caring for families in a context of crime, poverty and HIV/Aids?', paper presented at the Joint Conference of Academic Societies in
the Fields of Religion and Theology, Faculty of Theology, Stellenbosch University, the Fields of Religion and
Stellenbosch, 22-26 June

Dames, G.E., 2012, 'Intercultural Theological Education: Towards a New Future for Faculties of Theology at Higher Education Institutions in South Africa', Scriptura, Faculties of The
110 , in press.

De Beer, J.M. \& Van Niekerk, A.S., 2009, 'Die Missionêre Waarde van Belhar en die NG Kerk-Familie se Herenigingsgesprek: The Missional Value of Belhar and the DRC-Family's Reunification Talks', Nederduitse Gereformeerde Teologiese Tydskrif 50(1/2), 50-65.

De Klerk, B.J., De Wet, F.W. \& Letšosa, R.S., 2011, 'A Homiletic Reflection on the Theological Aesthetics Involved in Picturing God in a Fragmented South African Society', HTS Teologiese Studies/Theological Studies 67(2), Art. \#1018, 8 pages, viewed 20 January 2012, from http://dx.doi.org/10.4102/hts.v67i2.1018

Dewey, J., 1916, Democracy and education: An introduction in the philosophy of education, MacMillan, New York, NY.

Dewey, J., 1938, Logic: The theory of inquiry, Holt, New York, NY.

Dewey, J., 1951, Experience and education, MacMillan, New York, NY.

Dingemans, D.G.J., 1996, 'Practical Theology in the Academy: A Contemporary Overview', The Journal of Religion76, 83-96. http://dx.doi.org/10.1086/489737

Dreyer, J.S., 2002, 'Theological Normativity: Ideology or Utopia? Reflections on the Possible Contribution of Empirical Research', Practical Theology in SouthAfrica $17(2), 1-20$.

Dreyer, J.S., 2008, 'Practical Theology and Human Well-Being: An Exploration of a Multidimensional Model of Human Action as Conceptual Framework', Practical Theology in South Africa 23(3), 3-22.

Dreyer, J.S., 2009, 'Holistic Pastoral Ministry and the Challenges of Violence Against Women', paper presented at the Joint Conference of Academic Societies in the Fields of Religion and Theology, Faculty of Theology, Stellenbosch University, Stellenbosch, 22-26 June.

Firet, J., 1968, Het agogisch moment in het pastoraal optreden, Kok, Kampen.

Guder, D.L., 2000, The continuing conversion of the church, Eerdmans, Grand Rapids, MI. PMCid:110582

Habermas, J., 2001, On the pragmatics of social interaction: Preliminary studies in the theory of communicative action, transl. B. Fultner, MIT, Cambridge, MA.

Hastings, T.J., 2007, Practical theology and the one body of Christ: Toward a missional ecumenical model, Eerdmans, Grand Rapids, MI.

Hendriks, J., 1994, 'Missionêre Gemeentebou', Practical Theology in South Africa 9(2), 180-191.

Hendriks, J., 2001, 'Developing a Contextual, Missional Ecclesiology in Congregations Using a Practical Theological Methodology', Practical Theology in South Africa Using a Practic

Heitink, G., 1993, Praktische theologie: Geschiedenis, theorie, handelingsvelden, Kok, Kampen. PMid:8333911

Heitink, G., 2000, “'Ontwikkelingen in de praktische theologie”, (9): Een kroniek', Praktische Theologie 27(5), 538-558.

Immink, G., 2005, Faith: A practical theological reconstruction, Eerdmans, Grand Rapids, MN. PMCid:1091765

Janse van Rensburg, J., 2002, 'Die Postmoderne Mens aan wie die Evangelie Verkondig moet word', Practical Theology in South Africa 17(2), 39-60.

Janse van Rensburg, J., 2007, 'Voortsetting van die Epistomologiese Diskoers in die Praktiese Teologie: In Gesprek met J-A van den Berg', Practical Theology in South Africa 22(2), 61-80.

Janse van Rensburg, J., 2009, 'A holistic approach to pastoral care and poverty', paper presented at the Joint Conference of Academic Societies in the Fields of Religion and Theology, Faculty of Theology, Stellenbosch University, Stellenbosch, 22-26 June.

Keifert, P., 2006, A missional journey of spiritual discovery: We are here now, a new missional era, Allelon, Idaho, ID.

Koopman, N. \& Vosloo, R., 2002, Die ligtheid van die lig: Morele oriëntasie in ' $n$ postmoderne tyd, Lux Verbi, Kaapstad.

Kuperus, T., 2011, 'The Political Role and Democratic Contribution of Churches in Post-Apartheid South Africa', Journal of Church and State 53(2), 278-306, viewed 08 February 2012, from http://jcs.oxfordjournals.org/content/53/2/278.full. pdf +html

Landman, C., 2009, 'Gender-based violence and God-talk', paper presented at the Joint Conference of Academic Societies in the Fields of Religion and Theology, Faculty of Theology, Stellenbosch University, Stellenbosch, 22-26 June.

Lanser-van der Velde, A., 2000, Geloven leren: Een theoretisch en empirisch onderzoek naar wederkerig geloofsleren, Kampen, Kok.
Lanser, A., 2001, 'Denken en Doen: De Verhouding Theorie en Praktijk in de Praktische Vorming van de Pastor', Praktische Theologie 28(2), 233-247.

Laubscher, M., 2007, 'On Reading Karl Barth in South Africa Today: Karl Barth as Public Theologian?', HTS, Teologiese Studies/Theological Studies 63(4), 1549-1564, viewed 12 February 2012, from http://www.hts.org.za/index.php/HTS/article/ view/258

Louw, D.J., 2004, A pastoral hermeneutics of care and encounter, 5th edn., Lux Verbi, Wellington. PMCid:1223860

Louw, D.J., 2008, Cura vitae: Illness and the healing of life, Lux Verbi, Wellington.

Louw, D.J., 2009, 'Human Sexuality in an Eschatological Perspective: Towards an Aesthetics of Human Embodiment and Erotic Sensuality in Practical Theology', Practical Theology in SouthAfrica 24(1), 89-114.

McLaren, B.D., 2001, A new kind of Christian: A tale of two friends on a spiritual journey, Jossey-Bass, San Francisco, CA.

Meylahn, J.A., 2009, 'Holistic redemptive pastoral ministry in the fragmented transit hall of existence', paper presented at the Joint Conference of Academic Societies in the Fields of Religion and Theology, Faculty of Theology, Stellenbosch University, Stellenbosch, 22-26 June.

Marais, F., 2006, 'Pushing through the pain: An ethnographic reading of culture in post-apartheid South African congregations', paper presented at the KampenStellenbosch Consultation, Stellenbosch, 14-15 August. PMid:16959383

Mwambazambi, K., 2011, 'A Missiological Refection on African Ecclesiology', Verbum et Ecclesia 32(1), Art. \#482, 8 pages, viewed 15 February 2012, from: http://www. ve.org.za/index.php/VE/article/view/482

Moss, D., 2009, 'On Being “Non-Residential”: Reflections on Formation for Ministry', Theology Serving the Church since 1920 CXII(869), 1-20. http://dx.doi. org/10.1177/0040571X0911200504

Müller, J.C., 2005, 'A Postfoundationalist, HIV-Positive Practical Theology', Practical Theology in South-Africa 20(2), 72-88.

Müller, J.C., 2009, 'Holistic pastoral ministry in a time of transition', paper presented at the Joint Conference of Academic Societies in the Fields of Religion and Theology, Faculty of Theology, Stellenbosch University, Stellenbosch, 22-26 June.

Naidoo, M., 2010, 'Ministerial Training: The Need for Pedagogies of Formation and of Contextualisation in Theological Education', Missionalia 38(3), 347-368.

Nel, I., 2009, ' “Quo Vadis” Practical Theology?', Scriptura 100, 67-80.

Nel, M., 2002, 'Missionêre Koers van 58 Gemeentes in SA - 'n Empiriese Verslag', Practical Theology in South Africa 17(1), 54-75.

Newbigin, L., 1986, Foolishness to the Greeks: The gospel and western culture, Eerdmans, Grand Rapids, MI.

Newbigin, L., 1989, The gospel in a pluralist society, Eerdmans, Grand Rapids, MI.

Newbigin, L., 1996, Christian mission and modern culture: Truth and authority in modernity, Trinity Press, Pennsylvania, PA.

Newbigin, L., 1997, The gospel in today's global city, Selly Oak Colleges, Birmingham. PMid:9414554, PMCid:158607

Osmer, R.R., 2005, The teaching ministry of congregations, Eerdmans, Grand Rapids, MI.

Osmer, R.R., 2008, Practical theology: An introduction, Eerdmans, Grand Rapids, MI.

Osmer, R.R. \& Schweitzer, F.L., 2003, Developing a public faith: New directions in practical theology, Chalice, St Louis, MO.

Patton, J., 1988, 'Pastoral Ministry in a Fractured World', The Journal of Pastoral Care XLII(1), 26-36.

Pieterse, H.J.C., 2001, Preaching in a context of poverty, Unisa Press, Pretoria. PMCid:64867

Robinson, M., 2006, Planting mission-shaped churches today, Monarch, Oxford.

Roxburgh, A.J., 2005, The sky is falling!?! Leaders lost in transition, ACl Publishin, Eagle, ID.

Sampson, C., 2009, 'Ethical leadership in and through politics', in G.E. Dames (ed.), Ethical leadership for a morally transformed society, pp. 131-143, SunMedia, Stellenbosch.

Taylor, S., 2005, The out of bounds church? Learning to create a community of faith in a culture of change, Zondervan, Grand Rapids, MI.

Tshaka, R.S., 2007, 'African, You are on Your Own! The Need for African Reformed Christians to Seriously Engage their Africanity in Their Reformed Theological Reflections', Scriptura 96, 533-548.

Tucker, A.R., 2011, 'Practical Theology: Can it Really Help the Local Congregation?', HTS Teologiese Studies/Theological Studies, 67(2), Art. \#884, 10 pages, viewed 28 February 2012, from http://www.hts.org.za/index.php/HTS

Van den Berg, J.A., 2010, 'An (Auto)biographical theologia habitus - Future Perspectives for the Workplace', Acta Theologica Supplementum 13, 1-148.

Van der Ven, J., 1994, 'Empirical Methodology in PT: Why and How?', Practical Theology of South Africa 9(1), 29-44.

Viau, M., 1999, Practical theology: A new approach, Brill, Boston, MA.

Volf, M., 2011, A public faith: How followers of Christ should serve the common good, Brazos, Grand Rapids, Kindle edn., viewed 20 December 2011, from http://www. amazon.com/Practicing-Theology-Practices-Christian-ebook/dp/B004C44IFS/ ref=sr_1_17?s=digital-text\&ie=UTF8\&qid=1330003684\&sr=1-17

Walther, T., 2009, 'Interfaith Formation for Religious Leaders in a Multifaith Society: Between Meta-Spiritualities and Strong Religious Profiles', Formation and Supervision in Ministry 29, 128-134.

Wepener, C., 2005, 'Researching Rituals: On the Use of Participatory Action Research Within Liturgical Situations', Practical Theology in South-Africa 20(1), 109-127. 